\title{
THE COMPARISON OF TRAVELLERS' ATTITUDE TOWARDS PUBLIC TRANSPORT: A STUDY ON THE MODAL SHARE IN KUALA LUMPUR
}

\author{
*Noor Aqilah Ahmad Tajedi,a, Mohd Shahriman Shafein ${ }^{2, b}$, \\ SM Sabri SM Ismail ${ }^{3, c}$, Intan Rohani Endut ${ }^{4, d}$ \\ ${ }^{1}$ Research and Development, Syarikat Prasarana Negara Berhad, Kuala Lumpur, Malaysia \\ ${ }^{2}$ Post Graduate MITRANS, Universiti Teknologi MARA, Shah Alam, Malaysia \\ ${ }^{3}$ Research and Development, Syarikat Prasarana Negara Berhad, Kuala Lumpur, Malaysia \\ ${ }^{4}$ Faculty of Civil Engineering, Universiti Teknologi MARA, Shah Alam, Malaysia \\ anoor.aqilah@prasarana.com.my, bs shahriman.shafein@yahoo.com, \\ 'smsabri@prasarana.com.my, ${ }^{\mathrm{d}}$ intan@salam.uitm.edu.my
}

Keyword(s): Traveller Attitude, Age, Gender, Income level, Public Vehicle, Private Vehicle.

\begin{abstract}
A huge amount of investment has been made by the governments towards a public transportation sector by expecting that the infrastructure and sustainability of transportation could change the number of modal share gradually. However, the numbers of modal share have not increased compared to private vehicle usage of Kuala Lumpur, Malaysia. Therefore, a study on the travellers (both public and private vehicle users) attitudes is important to help understand the similarity or differences that could explain the modal share. The purpose of this study is to compare the attitudes of travellers in the Kuala Lumpur city centre by analysing the similarities and differences of attitudes among Public Transport users (PT) and Private Transport users (PV). The attitude being studied is about travelling without any specification of modes, thus examining 1790 KL dwellers objectives and provides the basis for fair and just comparison with regard to PT and PV. The attitudes towards travelling were measured by a 5-point Likert scale using a structured questionnaire, and statistically analysed by applying factor analysis provided in SPSS. The study found that six attitudes define the attitudes of PT traveller towards travelling, and three attitudes were influencing PV travellers toward travelling. Based on this outcome, the key attitudes that influence travellers' willingness to use public transport were discussed and identified. The results lead to understanding the attitudes of people towards travelling from the eye of public transport and private transport users.
\end{abstract}

\section{Introduction}

Kuala Lumpur (KL) has seen a rapid increment of car fleet, which has caused the whole transport system of KL to be overloaded, thus obstructing the mobility. As the number of cars and motorcycles has tripled in the last three decades, there are significant increases in road fatality especially among motorcyclist [1], [2]. Malaysia government introducing the rail-based transit networks and upgrades the stage buses service to accommodate ever-increasing travel demand and motorized transportation. Despite these efforts, the public transport modal share has plunged to the lowest figure of $10 \%$ to $12 \%$ in 2008 [3]. Through the implementation of National Key Areas initiatives on Public Transport (NKRA-UPT), the government initially targeted an increase of public transit mode share from $16 \%$ (2009) to $25 \%$ by 2012 . However, the NKRA-UPT annual report of 2012 revealed that this is a tough job as the mode share only increased to $20 \%$ by the year 2012 . The situation calls for urgent need to reverse the inclination towards private vehicle usage and increase the use of public transport [4]-[7]. This investment into more infrastructure development is not sufficient, and policy maker has to start looking into another important aspect of mode choice making; the human itself. 


\section{Public Transportation in Kuala Lumpur}

Presently, Kuala Lumpur offers variety of public transport modes consisting of metered taxis, buses and rail-based transit. RAPIDKL, one of the biggest public transport operator in Kuala Lumpur with $65 \%$ market share comprising of bus, monorail and LRT services. Taxis in Kuala Lumpur are operated by different taxi service operators. Although taxis can be easily hailed throughout the city with 24,721 licensed taxis in operation, bus services remain a popular mode of public transportation among city dwellers [8]. There are several bus operators operating in Kuala Lumpur, linking the city centre with the suburbs of the Klang Valley. Currently, there are four major private companies operating approximately 15,000 bus trips per day. Other bus operators include Metrobus, Selangor Omnibus, Transnasional/Kenderaan Klang-Banting, Triton, Permata Kiara and others[9]. The rail-based mode gain popularity and become significant since the implementation of the LRT systems back in 1998 and Kuala Lumpur monorail system since 2003. The upgrading of KTMB rail services and the operation are allows commuters to capture a significant portion of the long distance daily travel needs between Kuala Lumpur and the suburbs. Express Rail Link (ERL) provides two rail services, the KLIA Express and KLIA Transit servicing Kuala Lumpur up to Kuala Lumpur International Airport in Sepang, Selangor.

\section{Targeting the Attitudes of Traveller}

To encourage module shift from private vehicle to public transit, it is imperative policies to understand the decision maker's internal processes during preference formation and notably the role of factors that are not directly observable, such as attitudes or lifestyle preferences which has remained unexplained in traditional discrete choice analysis [10]. Thus study on travelling behavior and attitude may provide invaluable input to devise a practical and pragmatic transportation plan.

For the policies to impact highly on the residence of Kuala Lumpur, it is imperative to understand publics' attitudes towards using public transport. Understanding people's attitude has become main center of research since decades as it provide vital link to forecast people's intention and behavior, as evidence from various work done based on Ajzen (1991)'s Theory of Planned Behavior (TPB) [11]. There remains relatively small number of empirical studies that examine the attitude of travelers toward mode choice in developing countries especially in the South East Asia Region, even though several studies have looked into the observable criteria affecting mode choices such as mode attributes and journey characteristics [12], [13]. However, these studies lack in attention to unobservable factors especially the attitudinal variables.

Recent years, researchers have intensified the study into the traveler's attitude that contributes significantly toward mode of choice. The main focus is to identify the key attitudinal variables that influence mode of choice where a studies have identified several psychometric factors contribute. Latent variables such as lifestyle can highly influence individual's choice of mode due to the travel constrain and scheduling related to it [14], [15]. This provides insightful opportunities for policy makers and transit operators to study human aspect of mode choice decision-making process. Thus, it is imperative at this point to understand the psychological aspect of travelling, especially on the attitude of travelers. Comparison of the attitudes across socio-demographic variations is imperative in assisting policy makers to develop sound policies that could bring about alliances and generate necessary support from the targeted community.

To address the problem discussed earlier, this research aim to compare the traveler's attitudes toward travelling in light of four socio-demographic aspects: (1) gender, (2) types of vehicle user, (3) age ranges and (4) income levels. The research will focus on Kuala Lumpur, Malaysia as the area of interest. The aim will be achieved by systematically examining differences of attitudes towards travelling. At the end of the analysis, it is expected that the study will identify the differences and/or likeliness of the KL travelers' attitude towards travelling. This result provide significant basis to formulate policies and marketing strategies that best aligned to how KL traveler react/response toward public transportation. 


\section{Methodology}

This study was done quantitatively, and the data was gathered through questionnaire survey administered randomly to the public. The population is all individuals within 17-60 years of age using any kind of land transportation mode available in Kuala Lumpur. A total of 366 out of 450 respondents $(81.3 \%)$ are useable for data analysis. The data used to study the traveler's attitudes toward travel and willingness to use public transport were collected using the attitudinal questionnaire devised by Shiftan [16]. The first part included socio- demographic questions. The second part asked respondents about their travel habits for both work and non-work purposes. The third and main part of the survey inquired about 32 attitudinal variables that were used to measure respondents' sensitivity to a broad range of experiences that they might encounter during a trip, as well as characteristics of the different travel modes that they might consider for their journey. A Likert-type scale with odd number of response points was chosen because it is empirically more valid than forced choice scales [17]. The data analysis was done in both descriptive and statistical. The descriptive data analysis employs SPSS to quantitatively summarize the data to describe the sample and observations [18].

\section{Results}

\section{Demographic Characteristics}

From the result, depicts more than half were females (64.8\%) and the other 35.2\% were males. It is also shown that the largest group of respondents preferred to use cars $(46.4 \%)$ as their main choice of mode for travel. Also noticeable is the choice of bus as the preferred service when it comes to public transportation, arguably for its wide coverage as the fare is not among the cheapest in KL. In aggregate terms, the preference for private vehicle usage makes up more than half (73.8\%) compared to public transport (26.2\%).

Kuala Lumpur noticeably has high young adult population (18 to 40), and therefore, a high number of active travelling population. Majority of travellers are from emerging adulthood category (54.9\%). Household income is an important indicator of travel behaviour. The increase in household income provides households with greater purchasing power, enabling them to acquire more affluent household items such as private vehicles, whose ownership and consumption is indicative of the growth of mobility and preferred mode choice. The greatest number of respondents (157 persons/42.\%), indicated they lived in households with monthly income in the RM1,001 to $\mathrm{RM} 3,000$ range.

\section{Comparison of Attitudes}

Male travellers indicate that they need a reliable mode in term of time to avoid delays, even though they do not agree that they are always in a hurry to catch pre-planned activities that require them to travel. They also put the least favour on travelling with strangers, which might be related to their preference for travelling in consistent timing. Travelling with others (especially strangers) would affect the travel schedule as delays might be caused by others. Female travellers show reluctance to be the driver when travelling with others. This suggests preference to be the passenger, although it does not necessarily indicate a tendency to travel by public transport. There is statistically significant difference in two attitudes of travel; "Driving is usually the fastest way to get where I need to go" and "When I travel with others, I prefer to be the driver", both at $1 \%$ significance level.

Analysis into the differences between public and private vehicle users reveal that there are many differences between the two types of vehicle users, despite having reported almost the same preferences toward the most favourable attitudes. Both types of user show their preferences for consistent travel time and a clean vehicle, which explains their tendency to use own vehicles as they are in control of the cleanliness. 
Post hoc analysis using Mann-Whitneyy $U$ test reveals that 3 attitudes were significantly different; 1 attitude is significant at 1\% significance level (I prefer a travel option that has a predictable travel time of day to day), and 2 are significant at 5\% (If my travel options are delayed, I want to know the cause and length of the delay and When travelling, I like to keep as close as possible to my departure and arrival schedules). Middle-Old Adult were found to put more importance into their travel time, as all three attitudes that are significant display relevancy to predictable travel time, precise departure/arrival schedule and low tolerance toward delay in travel.

\section{Conclusion}

It is pertinent for policy makers and operators of public transport to understand the human aspect of transportation; namely the attitude that drives the whole decision process toward mode of travel. The knowledge can be used to optimize utilization of the valuable resources and effectively allocate the investment into high-impact sub-sector of transportation. The formulation of transport policies, public transport investment plans and measures to improve public transport services will be greatly assisted by knowing the dimension of which the attitudes of travellers differ which could provide a hint to their choice of mode. This particular finding may provide a policy direction in the long term by targeting the promotion among school/college students, who will be the future patrons of public transport.Further research on the choice of attitudinal attributes to be included in questionnaires, the inclusion of travel-behavior variables, and the use of SEM for more complex travel-behavior decisions, is required to refine this method.

Table 1 Mann-Whitney U Test of Independent Samples (Gender)

\begin{tabular}{|c|c|c|c|c|c|c|}
\hline \multirow[b]{2}{*}{ Description } & \multicolumn{2}{|c|}{ Male } & \multicolumn{2}{|c|}{ Female } & \multirow{2}{*}{$\begin{array}{l}\text { Mann- } \\
\text { Whitney U }\end{array}$} & \multirow{2}{*}{$\begin{array}{l}\text { M-W } \\
\text { Sig }\end{array}$} \\
\hline & $\begin{array}{l}\text { Mean } \\
\text { Rank }\end{array}$ & $\begin{array}{l}\text { Sum of } \\
\text { Ranks }\end{array}$ & $\begin{array}{l}\text { Mean } \\
\text { Rank }\end{array}$ & $\begin{array}{l}\text { Sum of } \\
\text { Ranks }\end{array}$ & & \\
\hline $\begin{array}{l}\text { Driving is usually the fastest way to get where I need to } \\
\text { go. }\end{array}$ & 204.12 & 26331.0 & 172.28 & 40830.0 & 12627.0 & $.004^{*}$ \\
\hline When I travel with others, I prefer to be the driver. & 209.79 & 27063.0 & 169.19 & 40098.0 & 11895.0 & $.000^{*}$ \\
\hline
\end{tabular}

* The mean difference is significant at the 0.01 level

** The mean difference is significant at the 0.05 level

Table 2 Mann-Whitney U Test of Independent Samples (Type of Transport Mode)

\begin{tabular}{lcccc}
\hline \multicolumn{1}{c}{ Description } & \multicolumn{2}{c}{ Mean Rank } & Mann-Whitney U & M-W Sig \\
\cline { 2 - 5 } & $\begin{array}{c}\text { Private } \\
\text { Vehicle }\end{array}$ & $\begin{array}{c}\text { Public } \\
\text { Vehicle }\end{array}$ & & $0.005^{* *}$ \\
\hline $\begin{array}{l}\text { Driving is usually the fastest way to get where I need to go } \\
\text { I feel safe using public transportation. }\end{array}$ & 192.39 & 158.51 & 10561.0 & $0.000^{*}$ \\
$\begin{array}{l}\text { I feel safe walking both near my home and near my } \\
\text { destination. }\end{array}$ & 172.72 & 213.81 & 10050.0 & $0.042^{*}$ \\
$\begin{array}{l}\text { It's important to be able to change my travel plans at a } \\
\text { moment's notice. }\end{array}$ & 191.29 & 161.60 & 10858.0 & $0.013^{*}$ \\
$\begin{array}{l}\text { I wouldn't mind walking a few minutes to get to and from } \\
\text { a bus and/or train. }\end{array}$ & 175.21 & 206.80 & 10723.0 & $0.009^{*}$ \\
$\begin{array}{l}\text { I know how to reach my destination using public } \\
\text { transportation. }\end{array}$ & 175.43 & 206.19 & 10781.5 & $0.011^{*}$ \\
$\begin{array}{l}\text { I would use public transportation more often if it were } \\
\text { cheaper to ride. }\end{array}$ & 172.60 & 214.16 & 10016.5 & $0.001^{*}$ \\
\hline
\end{tabular}

* The mean difference is significant at the 0.01 level

** The mean difference is significant at the 0.05 level

Table 3 Mann-Whitney U Test of Independent Samples (Age Range)

\begin{tabular}{|c|c|c|c|c|}
\hline \multirow[b]{2}{*}{ Description } & \multicolumn{2}{|c|}{ Mean Rank } & \multirow[b]{2}{*}{$\begin{array}{c}\text { Mann- } \\
\text { Whitney } \\
\text { U }\end{array}$} & \multirow[b]{2}{*}{$\begin{array}{c}\text { M-W } \\
\text { Sig }\end{array}$} \\
\hline & $\begin{array}{c}\text { Adolescent- } \\
\text { Emerging } \\
\text { Adult }\end{array}$ & $\begin{array}{c}\text { Middle } \\
\text {-Old } \\
\text { Adult }\end{array}$ & & \\
\hline I prefer a travel option that has a predictable travel time of day to day. & 170.21 & 204.71 & 12871.500 & $.001 *$ \\
\hline If my travel options are delayed, I want to know the cause and length of the delay. & 174.02 & 198.63 & 13729.500 & $.024 * *$ \\
\hline $\begin{array}{l}\text { When travelling, I like to keep as close as possible to my departure and arrival } \\
\text { schedules. }\end{array}$ & 172.93 & 200.37 & 13484.500 & $.012 * *$ \\
\hline I feel safe using public transportation. & 191.37 & 170.94 & 14091.500 & .055 \\
\hline
\end{tabular}

* The mean difference is significant at the 0.01 level

** The mean difference is significant at the 0.05 level 


\section{References}

[1] J. Mohamad, "Urban transport and growth management strategies : A tale of two Southeast Asian Cities at the dawn of the new millennium," Malaysian J. Soc. Sp., vol. 1, pp. 11-22, 2005.

[2] N. Shariff, "Private Vehicle Ownership and Transportation Planning in Malaysia," in International Conference on Traffic and Transportation Engineering (ICTTE, 2012, vol. 26, no. Ictte, pp. 64-68.

[3] PEMANDU, "Chapter 9: Improving Urban Public Tranport," Government Transformation Programme Annual Report 2012, 2013. [Online]. Available: http://www.pemandu.gov.my/gtp/annualreport2012/. [Accessed: 04-Oct-2013].

[4] J. Dargay, D. Gately, and M. Sommer, "Vehicle Ownership and Income Growth , Worldwide : 1960-2030," no. January, pp. 1-32, 2007.

[5] T. Litman, "Evaluating Public Transit Benefits and Costs - Best Practice Guidebook," Victoria, 2013.

[6] E. Sandow, "Til Work Do Us Part: The Social Fallacy of Long-distance Commuting," Urban Stud., vol. 51, no. 3, pp. 526-543, Aug. 2013.

[7] SPAD, "Greater KL/Klang Valley Land USe Plan," Land Public Transport Master Plan, 2014. [Online]. Available: http://www.spad.gov.my/sites/default/files/LU-MPMOC_110913-v1.0.pdf. [Accessed: 03-Jan-2014].

[8] SPAD, "Speech of Y.Bhg Tan Sri Syed Hamid Albar in Program Cambahan Ilmu UUM," Suruhanjaya Pengangkutan Awam Darat (S.P.A.D.), 2012. [Online]. Available: http://www.spad.gov.my/about-us/speeches/2012/program-cambahan-ilmu-uum. [Accessed: 24-Mar-2013].

[9] R. Kitamura and J. Mohamad, "Rapid motorization in Asian cities : urban transport infrastructure , spatial development and," Transportation (Amst)., vol. 36, no. 2, pp. 269274, 2009.

[10] D. Temme, M. Paulssen, and T. Dannewald, "Incorporating Latent Variables into Discrete Approach Using SEM Software,” BuR - Bus. Res., vol. 1, no. 2, pp. 220-237, 2008.

[11] I. Ajzen, "The theory of planned behavior," Organ. Behav. Hum. Decis., vol. 50, pp. 179211, 1991.

[12] A. N. Kmanba, "Modelling transport users' mode choice in Kuala Lumpur," Universiti Kebangsaan Malaysia, 2008.

[13] A. Nurdeen, "Mode Choice in Malaysia," Universiti Kebangsaan Malaysia, 2007.

[14] J. Pucher and J. Renne, "Socioeconomics of Urban Travel: Evidence from the 2001 National Household Travel Survey,” Transp. Q., vol. 57, no. 3, pp. 49-7849-78, 2003.

[15] J. Rubin, "Choosing Transit: The Influence of Past Travel Behavior, Attitudes and Habits on Present Choices," University of California, Berkeley, 2011.

[16] Y. Shiftan, M. L. Outwater, and Y. Zhou, "Transit market research using structural equation modeling and attitudinal market segmentation," J. World Conf. Transp. Res. Soc. Transp. Policy, vol. 15, no. 3, pp. 186-195, 2008.

[17] J. J. Ray, "Acquiescence and Problems with Forced-Choice Scales," J. Soc. Psychol., vol. 130, no. 3, pp. 397-399, Jun. 1990.

[18] D. R. Brillinger, H. K. Preisler, A. a Ager, and J. G. Kie, "An exploratory data analysis (EDA) of the paths of moving animals," J. Stat. Plan. Inference, vol. 122, no. 1-2, pp. 4363, May 2004. 